\title{
A Cytotoxic Rocaglate Compound from The Stembark of Aglaia argentea (Meliaceae)
}

\author{
Ace Tatang Hidayat ${ }^{1,2}$, Kindi Farabi ${ }^{1}$, Desi Harneti ${ }^{1}$, Nurlelasari ${ }^{1}$, Rani Maharani ${ }^{1,2}$, \\ Tri Mayanti ${ }^{1}$, Unang Supratman ${ }^{1,2, *}$, Yoshihito Shiono ${ }^{3}$ \\ ${ }^{1}$ Department of Chemistry, Faculty of Mathematics and Natural Sciences, \\ Universitas Padjadjaran, Jatinangor, Indonesia \\ ${ }^{2}$ Central Laboratory of Universitas Padjadjaran, Jatinangor, Indonesia \\ ${ }^{3}$ Department of Food, Life, and Environmental Science, Faculty of Agriculture, \\ Yamagata University, Tsuruoka, Yamagata, Japan \\ *email: unang.supratman@unpad.ac.id
}

Received June 15, 2017; Accepted September 25, 2017; Available online November 30, 2017

\begin{abstract}
The Aglaia genus belong to Meliceae family is unique plant species because the presence of rocaglate and rocaglamide which is so far isolated only from Aglaia genus, indicate that type of this compound as a chemical marker for the genus of Aglaia. This type of compound known to have strong activity, such as insecticide and cytotoxic. This study describe the isolation, structure elucidation, and cytotoxic activity of an isolated rocaglate compound. Dried stembark of A. argentea extracted with methanol and partition between $n$-hexane, ethyl acetate, and $n$-butanol, respectively The extracts were tested against P-388 murine leukemia cells and the ethyl acetat showed strongest activity with $\mathrm{IC}_{50}$ value of $15.5 \mu \mathrm{g} / \mathrm{mL}$. The ethyl acetate then was separated and purified with chromatography technique to obtain isolated compound $\mathbf{1}$. The chemical structure of isolated compounds were elucidated by spectroscopic methods including one and two-dimensional NMR as well as high-resolution mass spectrometric analysis and identified as a methyl rocaglate. Compound $\mathbf{1}$ showed strong cytotoxic activity with an $\mathrm{IC}_{50}$ value of $<0.1 \mu \mathrm{g} / \mathrm{mL}$.
\end{abstract}

Keywords: Aglaia, Aglaia argentea, cytotoxic activity, methyl rocaglate, , P-388 murine leukemia cells.

\section{INTRODUCTION}

Aglaia is the largest genus belong to Meliaceae family contain more than 150 species ( $\mathrm{Su}$ et al., 2006; Awang et al., 2012) and about 65 species grown in Indonesia (Wood, Silverstain \& Nakajima, 1970). This genus is an important component of the tropical rain forest in the Indomalesiana area (Muellner et al., 2010) and mainly distributed in tropical countries including India, Indonesia, Malaysia and parts of the Western Pacific (Pannell, 1992; Inada et al., 2001). On the basis of literature study, phytochemical studies on Aglaia species have led to the identification and isolation of main compounds such as sesquiterpenoids (Joycharat, Plodpai, Panthong, Yingyongnarongkul \& Voravuthikunchai, 2010; Liu, et al., 2014), diterpenoids (Cai, Wang, Zhao, Li \& Luo, 2010; Yodsaoue et al., 2012), rocaglate derivatives (Ishibashi, Satastook, Isman \& Towers, 1993; Wu et al., 1997; Nugroho et al., 1999), lignans (Wang et al., 2004; Sianturi et al., 2016), dammarane-type triterpenoids (Roux et al., 1998; Khalit et al., 1999; Xie, Yang, Chen, \& Yue, 2007; Zhang, wang, Gu, \& Kong, 2010; Harneti et al., 2012, Farabi et al., 2017) and cycloartane-type triterpenoids (Khalit et al., 1999; Awang et al., 2012).
Members of the Aglaia genus have recently received considerable attention due to the presence of a structurally unique group of cyclopentabenzofurans, the so-called rocaglamide derivatives, which occur exclusively in this genus (Ishibashi et al., 1993; Wu et al., 1997; Nugroho et al., 1999). The parent compound rocaglamide and many of its congeners are potent natural insecticides comparable in activity to azadirachtin (Nugroho et al., 1999; Chaidir et al., 1999; 2001) In addition to their insecticidal activity, the rocaglamides exhibit pronounced antiproliferative activity against human cancer cells in vitro, comparable to that of vinblastine sulfate (Chaidir et al., 2001; Bohnenstengel et al., 1999), thus making these compounds an even more fascinating group of potently bioactive plant secondary metabolites.

During the course of our continuing search for anticancer candidate compounds from Indonesia Aglaia plants, we isolated and described cytotoxic triterpenoids from the bark of A. smithii and A. eximia (Harneti et al., 2012 ; 2014) as well as a lignan and bisamides from the bark of $A$. eximia (Sianturi et al., $2015 ; 2016$ ). In the further screening for cytotoxic compounds from Indonesia Aglaia 
species, we found that ethyl acetate extracts of the bark of $A$. argentea exhibited a significant cytotoxic activity against $\mathrm{P}-388$ murine leukemia cells with $\mathrm{IC}_{50}$ value of $15.48 \pm 0.03$ $\mu \mathrm{g} / \mathrm{mL}$. A. argentea, also known as langsat hutan in Indonesia is a higher plant traditionally used to moisturizing the lungs, reducing fever and for treating contused wound, coughs and skin diaseases (Mabberley, Pannel, \& Sing., 1995; Muellner et al., 2010).

Previous phytochemical studies of $A$. argentea has revealed the presence of a compounds with cytotoxic activity against $\mathrm{KB}$ cells, including cycloartane-type triterpenoids (Omobuwajo et al., 1995) and 3,4-secoapo tirucallane-type triterpenoids (Mohamad et al., 1999). Although secondary metabolites of other Aglaia species have been investigated previously, the rocaglamide derivatives of $A$. argentea is yet to be reported. We report herein the isolation and structure identification of rocaglate compound along with its cytotoxic activity against P-388 murine leukimia cells that not yet invertigated previously.

\section{EXPERIMENTAL SECTION}

\section{Plant Material}

The stembark of $A$. argentea were collected in Bogor Botanical Garden, Bogor, West Java Province, Indonesia in June 2015. The plant was identified by the staff of the Bogoriense Herbarium, Research Center for Biology, Indonesian Institute of Science, Bogor, Indonesia and a voucher specimen (No. Bo-1288718) has been deposited at the herbarium.

\section{General Experimental Procedure}

The IR spectra were recorded on a Perkin-Elmer spectrum-100 FT-IR (Waltwam, MA, USA) in $\mathrm{KBr}$. Mass spectra were obtained with a Synapt G2 mass spectrometer instrument (Waters, Milford, MA, USA). ${ }^{1} \mathrm{H}$, ${ }^{13} \mathrm{C}$, DEPT NMR spectral data and ${ }^{1} \mathrm{H}^{-1}{ }^{1} \mathrm{H}$ COSY, HMQC and HMBC experiments were performed on a JEOL ECZ-600 spectrometer at $600 \mathrm{MHz}$ (Tokyo, Japan) with $\mathrm{CDCl}_{3}$ as a solvent, chemical shifts are given on a $\delta$ (ppm) scale and tetramethylsilane (TMS) as an internal standard. Column chromatography was conducted on silica gel 60 (Kanto Chemical Co., Inc., Japan) and (Merck, Darmstadt, Germany). Preparative MPLC using a Buchi Pump Controller C-610, Buchi Pump Modules C-605 with FLH-R10030B
SiliCycle column- ISO04 Siliasep ${ }^{\mathrm{TM}}$ (Buchi, Swizerland). TLC plates were precoated with silica gel $\mathrm{GF}_{254}$ (Merck, $0.25 \mathrm{~mm}$ ) and detection was achieved by spraying with $10 \%$ $\mathrm{H}_{2} \mathrm{SO}_{4}$ in $\mathrm{EtOH}$, followed by heating and under ultra-violet light at wavenumber 254 and 367 $\mathrm{nm}$.

\section{Extraction and Isolation}

The crushed and dried bark $(2.5 \mathrm{~kg})$ of A. argentea was extracted with methanol (12 L) at room temperature for 5 days. The methanol extract was evaporated under reduce pressure to give concentrated of $\mathrm{MeOH}$ extract $(133.5 \mathrm{~g})$. The concentrated $\mathrm{MeOH}$ extract was first suspended in $\mathrm{H}_{2} \mathrm{O}$ and then partitioned successively with $n$-hexane (4 L), EtOAc (4 L) and $n$-butanol $(4 \mathrm{~L})$. The EtOAc layer was subsequently dried over anhydrous sodium sulfate, filtered, and evaporated to dryness. The EtOAc soluble fraction (12.1 g) was fractionated by column chromatography on silica gel using a gradient $n$-hexane-EtOAc to give eight fractions $(\mathrm{A}-\mathrm{H})$. Fraction $\mathrm{D}(1.12 \mathrm{~g})$ was chromatographed on a Medium Presure Liquid Chromatography (MPLC) column of silica gel, eluted with $\mathrm{CHCl}_{3}$-EtOAc (50:1), to give eight subfractions (D01-D08). Subfraction D05 was separated on preparative TLC silica gel $\mathrm{GF}_{254}$, eluted with $n$ hexane: $\mathrm{Me}_{2} \mathrm{CO}(7: 3)$, to give $\mathbf{1}(10 \mathrm{mg})$.

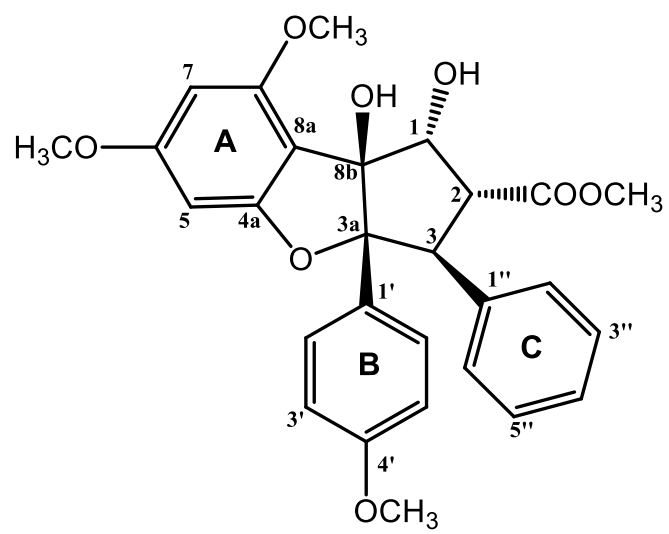

Figure 1. Chemical structure of compound 1.

\section{Determination of Cytotoxic Activity}

The cytotoxicity assay was conducted according to the method described by Sahidin et al., 2005 and Alley et al., 1998. P-388 cells were seeded into 96-well plates at an initial cell density of approximately $3 \times 10^{4}$ cells cm 3 . After $24 \mathrm{~h}$ of incubation for cell attachment and growth, varying concentrations of samples were added. The compounds added were first dissolved in DMSO at the required 
concentration. Subsequent six desirable concentrations were prepared using PBS (phosphoric buffer solution, $\mathrm{pH}=7.30$ - 7.65). Control wells received only DMSO. The assay was terminated after a $48 \mathrm{~h}$ incubation period by adding MTT reagent [3-(4,5dimethylthiazol-2-yl)-2,5-diphenyl tetrazolium bromide; also named as thiazol blue] and the incubation was continued for another $4 \mathrm{~h}$, in which the MTT-stop solution containing SDS (sodium dodecyl sulphate) was added and another $24 \mathrm{~h}$ incubation was conducted. Optical density was read by using a micro plate reader at $550 \mathrm{~nm}$. $\mathrm{IC}_{50}$ values were taken from the plotted graph of percentage live cells compared to control (\%), receiving only PBS and DMSO, versus the tested concentration of compounds $(\mu \mathrm{g} / \mathrm{mL})$. The $\mathrm{IC}_{50}$ value is the concentration required for $50 \%$ growth inhibition. Each assay and analysis was run in triplicate and averaged.

\section{RESULT AND DISCUSSION}

The dried bark of $A$. eximia were grounded and successively extracted with $n$-hexane, ethyl acetate and methanol. All of the extracts were evaluated cytotoxic activity against P-388 murine leukimia cells and the ethyl acetate showed strongest cytotoxic activity. Subsequent phytochemical analysis was therefore focused on the ethyl acetate extract. By using the cytotoxic activity to follow the separations, the ethyl acetate extract was chromatographed over a vacuum-liquid chromatographed (VLC) column packed with silica gel 60 by gradient elution. The VLC fractions were repeatedly subjected to normalphase column chromatography, medium presure liquid chromatography and preparative thin layer chromatography (PTLC) on silica gel $\mathrm{GF}_{254}$ to afford a cytotoxic compounds 1 (Figure 1).

Compound 1 was obtained as a white amorphous powder. The High Resolution Time of Flight Mass spectroscopy (HRTOFMS) spectrum showed $[\mathrm{M}+\mathrm{H}]^{+} \mathrm{m} / \mathrm{z} 493.1870$ (calcd. $\mathrm{m} / z$ 492.1874), which corresponded to the molecular formula of $\mathrm{C}_{28} \mathrm{H}_{28} \mathrm{O}_{8}$ thus requiring fifteen degrees of unsaturation. The IR spectra showed absorption peaks at $3430 \mathrm{~cm}^{-1}(\mathrm{OH})$, 2985 (C-H aliphatics), $1675 \mathrm{~cm}^{-1}$ (conjugated carbonyl), $1560(\mathrm{C}=\mathrm{C}$ aromatics $), 1478 \mathrm{~cm}^{-1}$ ( $\mathrm{C}=\mathrm{C}$ olefinic), $1168 \mathrm{~cm}^{-1}$ (asymmetric C-O-C stretch) and $825 \mathrm{~cm}^{-1}$ (substituted benzene). The ${ }^{1}$ H-NMR spectrum of compound 1 showed a characteristic $\mathrm{AA}^{\prime} \mathrm{BB}^{\prime}$ pattern of $\mathrm{B}$ ring at $\delta_{\mathrm{H}}$ $7.10(2 \mathrm{H}, \mathrm{dd}, J=1.8,6.6 \mathrm{~Hz})$ and $\delta_{\mathrm{H}} 6.66(2 \mathrm{H}$, $\mathrm{dd}, J=1.8,6.6 \mathrm{~Hz}$ ), corresponding to $\mathrm{H}-2^{\prime} / \mathrm{H}-$ $6^{\prime}$ and $\mathrm{H}^{\prime} 3^{\prime} / \mathrm{H}-5^{\prime}$ in benzene ring. The resonances of two meta-coupling protons of ring A were observed at $\delta_{\mathrm{H}} 6.27(1 \mathrm{H}, \mathrm{d}, J=1.8$ $\mathrm{Hz}, \mathrm{H}-5)$ and $\delta_{\mathrm{H}} 6.11(1 \mathrm{H}, d, J=1.8 \mathrm{~Hz}, \mathrm{H}-7)$. The addition of olefinic signal at $\delta_{\mathrm{H}} 7.04(2 \mathrm{H}$, $\mathrm{m})$ and $6.85(2 \mathrm{H}, \mathrm{m})$, indicate the presence of $\mathrm{C}$ ring as a monosubstituted benzene ring. Resonance of signals at $\delta_{\mathrm{H}} 3.63,3.69,3.82$, and 3.86 (each $3 \mathrm{H}, \mathrm{s}$ ) were assigned that compound 1 have four methoxy groups. The oxymethine protons at $\delta_{\mathrm{H}} 5.01(1 \mathrm{H}, \mathrm{d}, J=6$ $\mathrm{Hz}, \mathrm{H}-1), 3.89$ (1H, dd, $J=6.6,14.4 \mathrm{~Hz}, \mathrm{H}-2)$, and 4,28 $(1 \mathrm{H}, \mathrm{d}, J=13,8 \mathrm{~Hz}, \mathrm{H}-3)$, which very similar with characteristic of core skeleton in cyclopenta $[b]$ benzofuran-type rocaglate (Othman et al., 2016). The ${ }^{13} \mathrm{C}-\mathrm{NMR}$ spectrum showed twenty eight carbon resonances, which were classified by their chemical shifts and DEPT (Distortionless Enhancement by Polarization Transfer) spectra as four methoxy, fourteen methines, and ten quaternary carbons, include eighteen $s p^{2}$ carbons (eleven methines and seven quartenary carbons). This functionalities accounted for ten out of the total fifteen degrees of unsaturation. The remaining of five degree of unsaturation were consistent with cyclopenta[ $b]$ benzofurantype rocaglate skeleton to form three benzene ring and an ester group at $\mathrm{C}-2$, which resonating at $\delta_{\mathrm{C}} 170.7 \mathrm{ppm}$. To determine the connectivity of the partial structure due to the presence of methoxy, hydroxy and ester groups, ${ }^{1} \mathrm{H}-{ }^{1} \mathrm{H}$ COSY (correlated spectroscopy) and HMBC (Heteronuclear multiplicity bond connectivity) experiments were carried out, and the results are shown in Figure 2. The ${ }^{1} \mathrm{H}$ ${ }^{1} \mathrm{H}$ COSY spectra confirm for neighboring protons at $\mathrm{H}-1 / \mathrm{H}-2 / \mathrm{H}-3$ in core skeleton, $\mathrm{H}-$ $2^{\prime} / \mathrm{H}-3^{\prime}$ and $\mathrm{H}-5^{\prime} / \mathrm{H}-6^{\prime}$ in $\mathrm{B}$ ring, $\mathrm{H}-2^{\prime \prime} / \mathrm{H}-3^{\prime \prime} / \mathrm{H}-$ $4^{\prime \prime} / \mathrm{H}-5^{\prime \prime} / \mathrm{H}-6^{\prime \prime}$ in $\mathrm{C}$ ring. All these data showed in line to the ${ }^{1} \mathrm{H}$ NMR spectrum. In the HMBC spectrum, two meta-coupling protons of $\mathrm{A}$ ring, $\mathrm{H}-5$ at $\delta_{\mathrm{H}} 6.27(1 \mathrm{H}, \mathrm{d}, J=1.8 \mathrm{~Hz})$ and $\mathrm{H}-7$ at $\delta_{\mathrm{H}} 6.11(1 \mathrm{H}, \mathrm{d}, J=1.8 \mathrm{~Hz})$ exhibited correlations to C-6 $\left(\delta_{\mathrm{C}} 164.2\right)$ and $\mathrm{C}-8\left(\delta_{\mathrm{C}}\right.$ 157.2), indicate that two methoxy groups attach to C-6 and C-8, respectively. The other methoxy group was determined by correlation of methoxy signal at $\delta_{\mathrm{H}} 3.69(3 \mathrm{H}, \mathrm{s})$ to $\mathrm{C}-4^{\prime}\left(\delta_{\mathrm{C}}\right.$ 158.8 ), indicated that another methoxy group was atteched to C-4. 
Table 1. NMR data for $\mathbf{1}\left(600 \mathrm{MHz}\right.$ for ${ }^{1} \mathrm{H}$ and $150 \mathrm{MHz}$ for ${ }^{13} \mathrm{C}$, in $\mathrm{CDCl}_{3}$ ) and methyl rocaglate (An et al., 2016)

\begin{tabular}{|c|c|c|c|c|}
\hline \multirow[b]{2}{*}{ No. } & \multicolumn{2}{|r|}{1} & \multicolumn{2}{|r|}{ methyl rocaglate } \\
\hline & $\begin{array}{l}{ }^{13} \mathrm{C} \text { NMR } \\
\delta c \text { (mult.) }\end{array}$ & $\begin{array}{c}{ }^{1} \mathrm{H} \text { NMR } \\
\delta_{\mathrm{H}}(\text { Integral, mult., } J=\mathrm{Hz})\end{array}$ & $\begin{array}{l}{ }^{13} \mathrm{C} \text { NMR } \\
\delta \mathrm{c} \text { (mult.) }\end{array}$ & $\begin{array}{c}{ }^{1} \mathrm{H} \text { NMR } \\
\delta_{\mathrm{H}}(\text { Integral, mult., } J=\mathrm{Hz})\end{array}$ \\
\hline 1 & $79.6(d)$ & $5.01(1 \mathrm{H}, \mathrm{d}, 6)$ & $79.8(\mathrm{~d})$ & $5.02(1 \mathrm{H}, \mathrm{dd}, 1.6,6.8)$ \\
\hline 2 & $50.5(\mathrm{~d})$ & $3.89(1 \mathrm{H}, \mathrm{dd}, 6.6,14.4)$ & $50.5(\mathrm{~d})$ & $3.91(1 \mathrm{H}, \mathrm{dd}, 6.8,14.4)$ \\
\hline 3 & $55.0(\mathrm{~d})$ & $4.28(1 \mathrm{H}, \mathrm{d}, 13.8)$ & 55.0 (d) & $4.32(1 \mathrm{H}, \mathrm{d}, 13.4)$ \\
\hline $3 a$ & $101.9(\mathrm{~s})$ & - & $102.2(\mathrm{~s})$ & - \\
\hline $4 a$ & $160.9(\mathrm{~s})$ & - & $160.7(\mathrm{~s})$ & - \\
\hline 5 & $89.5(d)$ & $6.27(1 \mathrm{H}, \mathrm{d}, 1.8)$ & $93.4(\mathrm{~d})$ & $6.29(1 \mathrm{H}, \mathrm{d}, 2.4)$ \\
\hline 6 & $164.2(\mathrm{~s})$ & - & $167.7(\mathrm{~s})$ & - \\
\hline 7 & $92.7(\mathrm{~d})$ & $6.11(1 \mathrm{H}, \mathrm{d}, 1.8)$ & $93.6(d)$ & $6.13(1 \mathrm{H}, \mathrm{d}, 2.4)$ \\
\hline 8 & $157.0(\mathrm{~s})$ & - & $157.2(\mathrm{~s})$ & - \\
\hline $8 a$ & $107.8(\mathrm{~s})$ & - & $110.0(\mathrm{~s})$ & - \\
\hline $8 b$ & $93.8(\mathrm{~s})$ & - & $93.5(\mathrm{~s})$ & - \\
\hline 6-OMe & $55.8(\mathrm{q})$ & $3.82(3 \mathrm{H}, \mathrm{s})$ & $55.7(\mathrm{q})$ & $3.88(3 \mathrm{H}, \mathrm{s})$ \\
\hline 8-OMe & $55.9(\mathrm{q})$ & $3.86(3 \mathrm{H}, \mathrm{s})$ & $56.0(\mathrm{q})$ & $3.84(3 \mathrm{H}, \mathrm{s})$ \\
\hline $1^{\prime}$ & $126.4(\mathrm{~s})$ & - & $126.4(\mathrm{~s})$ & - \\
\hline $2^{\prime}, 6^{\prime}$ & $129.1(\mathrm{~d})$ & $7.10(2 \mathrm{H}, \mathrm{dd}, 1.8,6.6)$ & $129.1(\mathrm{~d})$ & $7.11(1 \mathrm{H}, \mathrm{d}, 8.8)$ \\
\hline $3^{\prime}, 5^{\prime}$ & $112.8(\mathrm{~d})$ & $6.66(2 \mathrm{H}, \mathrm{dd}, 1.8,6.6)$ & $112.7(\mathrm{~d})$ & $6.68(1 \mathrm{H}, \mathrm{d}, 8.8)$ \\
\hline $4^{\prime}$ & $158.8(\mathrm{~s})$ & - & $158.8(\mathrm{~s})$ & - \\
\hline $4^{\prime}-\mathrm{OMe}$ & $55.2(\mathrm{q})$ & $3.69(3 \mathrm{H}, \mathrm{s})$ & $55.1(\mathrm{q})$ & $3.71(3 \mathrm{H}, \mathrm{s})$ \\
\hline $1^{\prime \prime}$ & $135.9(\mathrm{~s})$ & - & $136.9(\mathrm{~s})$ & - \\
\hline $2^{\prime \prime}, 6^{\prime \prime}$ & $127.8(\mathrm{~d})$ & $7.04(2 \mathrm{H}, \mathrm{m})$ & $127.9(\mathrm{~d})$ & $6.88(2 \mathrm{H}, \mathrm{m})$ \\
\hline $3^{\prime \prime}, 5^{\prime \prime}$ & $127.9(\mathrm{~d})$ & $6.85(2 \mathrm{H}, \mathrm{m})$ & $127.7(d)$ & $7.07(2 \mathrm{H}, \mathrm{m})$ \\
\hline $4^{\prime \prime}$ & $126.7(d)$ & $7.04(1 \mathrm{H}, \mathrm{m})$ & $126.6(d)$ & $6.88(2 \mathrm{H}, \mathrm{m})$ \\
\hline $2-\mathrm{CO}_{2} \mathrm{CH}_{3}$ & $170.7(\mathrm{~s})$ & - & $170.4(\mathrm{~s})$ & - \\
\hline $2-\mathrm{CO}_{2} \mathrm{CH}_{3}$ & $52.1(\mathrm{q})$ & $3.63(3 \mathrm{H}, \mathrm{s})$ & $51.9(\mathrm{q})$ & $3.65(3 \mathrm{H}, \mathrm{s})$ \\
\hline
\end{tabular}

The correlation between $\mathrm{H}-2^{\prime}\left(\delta_{\mathrm{H}} 7.10\right.$ ppm) to $\mathrm{C}-3 \mathrm{a}\left(\delta_{\mathrm{C}} 101.9\right)$, showed that tetra substituted benzene (B ring) was attached to $\mathrm{C}-3 \mathrm{a}$. The presence of mono-substitued benzene ring ( $\mathrm{C}$ ring) at $\mathrm{C}-3$ was supported by correlation between $\mathrm{H}-3\left(\delta_{\mathrm{H}} 4.28\right)$ to $\mathrm{C}-1$ " $\left(\delta_{\mathrm{C}}\right.$ $135.9)$ and $C-2^{\prime \prime}\left(\delta_{C} 127.8\right)$. The position of ester group in $\mathrm{C}-2$ was determined by correlation of methoxy group $\left(\delta_{\mathrm{H}} 3.63\right)$ and $\mathrm{H}$ $2\left(\delta_{\mathrm{H}} 3.89 \mathrm{ppm}\right)$ to ester carbonyl at $\delta_{\mathrm{C}} 170.7$ ppm. An oxygenated methine at $\delta_{\mathrm{H}} 5.01\left(\delta_{\mathrm{C}}\right.$ 89.5) were correlated to an oxygenated carbon at $\mathrm{C}-8 \mathrm{~b}\left(\delta_{\mathrm{C}} 93.8\right)$ and $\mathrm{C}-2\left(\delta_{\mathrm{C}} 50.5\right)$, indicated that secondary and tertiary alcohols were located at C-1 and C-8b, respetively.

The stereochemistry of $\mathbf{1}$ was determined by comparation to those coupling constant in ${ }^{1} \mathrm{H}$ NMR spectra $\left({ }^{1,2} J\right.$ and $\left.{ }^{2,3} J\right)$ and chemical shift of ${ }^{13} \mathrm{C}$ NMR spectra with previously literature data along with biogenetic point of view the occurance of cyclopenta[b]benzofuran-type rocaglate in Aglaia genus (Othman et al., 2016). The full assignments of compound $\mathbf{1}$ are shown in Table 1. Comparison of the NMR data of $\mathbf{1}$ with those of methyl rocaglate previously reported (An et al., 2016) showed high similarity, consequently compound $\mathbf{1}$ was identified as a methyl rocaglate and showed in this plant for the first time.

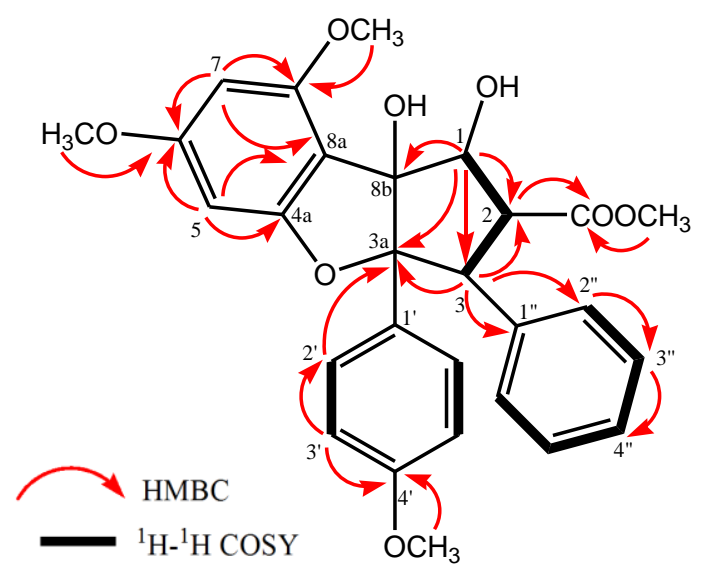

Figure 2. Selected $\mathrm{HMBC}$ and ${ }^{1} \mathrm{H}-{ }^{1} \mathrm{H}$ COSY correlations for $\mathbf{1}$. 
The cytotoxicity effects of the isolated compound 1 against P-388 murine leukemia cells were investigated according to the method described in previous papers (Harneti et al., 2012; Sianturi et al., 2015) and artonin E $\left(\mathrm{IC}_{50} 0.3 \mu \mathrm{g} / \mathrm{mL}\right.$ ) was used as a positive control (Hakim et al., 2007). The cytotoxic activity of isolated compound $\mathbf{1}$ showed very strong activity with in $\mathrm{IC}_{50}$ value of $<0.1 \mu \mathrm{g} / \mathrm{mL}$.

Rocaglate compounds known as cytotoxic agent. Since rocaglate and its derivatives have been found to have anticancer activities in experimental animal models, efforts have been taken to explore the molecular mechanisms of their actions. In several early publications, rocaglate derivatives were reported to function mainly in a cytostatic rather than a directly cytotoxic manner (Bohnenstengel et al., 1999; Lee, Cui, Mehta, Kinghorn \& Pezzuto, 1998). It was shown that treatment of the human lung carcinoma cells Lu1 with 40-demethoxy30,40-methylenedioxy-methyl rocaglate resulted in inhibition of tumor cell proliferation with cell accumulation in the G1/G0 phase of the cell cycle with only marginal cell death. Thereafter, didesmethyl-rocaglamide, aglaroxin D (aglaiastatin), and silvestrol were shown to inhibit cell proliferation of different human malignant cell lines with the cell cycle blocked at the G2/M phase with negligible death. Based on these observations, it was thought that inhibition of translation is the key mode of action by which cyclopenta $[b]$ benzofurans exert their antitumor activities. Induction of apoptosis is now known to be also an important mechanism of rocaglamide mediated anticancer activity (Ebada et al., 2011).

\section{CONCLUSION}

A rocaglate-type compound was identified as a methyl rocaglate (1) has been isolated from the stembark of Aglaia argentea for first time. This investigation supported the occurance of rocaglate-type compound in Aglaia genus. Methyl rocaglate 1, was evaluated for its cytotoxic activity against P-388 murine leukemia cells, in vitro and showed strong cytotoxic activity with $\mathrm{IC}_{50}$ value of $<0.1$ $\mu \mathrm{g} / \mathrm{mL}$. A rocaglate is a unique compound only isolated from Aglaia genus. This type of compound known as a cytotoxic agent to inhibit cell proliferation and cell translation.

\section{ACKNOWLEDGMENT}

This research was financially supported by Directorate General of Higher Education, Ministry of Science, Technology and Higher Education, Indonesia (Postgraduate Grant, 2015-2016 by US). We thank Mrs. Suzany Dwi Elita at Department of Chemistry, Faculty of Mathemathics and Natural Sciences, Institut Teknologi Bandung, Indonesia for cytotoxicity bioassay.

\section{REFERENCES}

An, F.L., Wang, X.B., Wang, H., Li, Z.R., Yang, M.H., Luo, J., Kong, L.Y. (2016). Cytotoxic rocaglate derivatives from leaves of Aglaia perviridis. Nature, 6, 20045.

Awang, K., Loong, X.M., Leong, K.H., Supratman, U., Litaudon, M., Mukhtar, M.R., \& Mohamad, K. (2012). Triterpenes and steroids from the leaves of Aglaia exima (Meliaceae). Fitoterapia, 83, 1391-1395.

Bohnenstengel, F.I., Steube, K.G., Meyer, C., Nugroho, B.W., Hung, P.D., Kiet, L.C., \& Proksch, P. (1999). Structure activity relationships of antiproliferative rocaglamide derivatives from Aglaia species (Meliaceae). Z Naturforsch, 54c, 55.

Cai, X., Wang, Y., Zhao, P., Li, Y., \& Luo, X. (2010). Dolabellane diterpenoids from Aglaia odorata. Phytochemistry, 71, 1020-1024.

Chaidir, Hiort, J., Nugroho, B.W., Bohnenstengel, F.I., Wray, V., Witte, L., Hung, P.D., Kiet, L.C., Sumaryono, W., \& Proksch, P. (1999). New insecticidal rocaglamide derivatives from fowers of Aglaia duperreana (Meliaceae). Phytochemistry, 52, 837-842

Chaidir, Lin, W.H., Ebel, R., Edrada, R., Wray, V., Nimtz, M., Sumaryono, W., \& Proksch, P. (2001). Rocaglamides, Glycosides, and Putrescine Bisamides from Aglaia dasyclada. Journal of Natural Products, 64, 1216-1220.

Ebada, S.S., Lajkiewicz, N., Porco, J.A., LiWeber, M., \& Proksch, P. (2011). Chemistry and biology of rocaglamides (flavaglines) and related derivatives from Aglaia species (Meliaceae). Progress in the Chemistry of Organic 
Natural Products Vol. 94. Springer. London.

Farabi, K., Harneti, D., Nurlelasari., Maharani, R., Hidayat, A.C., Awang, K., Supratman, U., \& Shiono, Y. (2017). New cytotoxic protolimonoids from the stem bark of Aglaia argentea (Meliaceae). Phytochemistry Letters, 21, 211-215.

Hakim, E.H., Achmad, S.A., Juliawaty, L.D., Makmur, L., Syah, Y.M., Aimi, A., Kitajima, M., Takayama, H., \& Ghisalberti, E.L. (2007). Prenylated flavonoids and related compounds of the Indonesian Artocarpus (Moraceae). Journal of Natural Medicine, 61(2), 229-236.

Harneti, D., Tjokronegoro, R., Safari, A., Supratman, U., Loong, X.M., Mukhtar, M.R., Mohamad, K., Awang, K., \& Hayashi, H. (2012). Cytotoxic triterpenoids from the bark of Aglaia smithii. Phytochemistry Letters, 5, 496499.

Harneti, D., Supriadin, A., Ulfah, M., Safari, A., Supratman, U., Awang, K., Hayashi, H. (2014). Cytotoxic constituents from the bark of Aglaia eximia (Meliaceae). Phytochemistry Letters, 8 28-31.

Inada, A., Sorano, T., Murata, H., Inatomi, Y., Darnaedi, D., \& Nakanishi, T. (2001). Diamide derivatives and cycloartanes from the leaves of Aglaia elliptica. Chemical and Pharmaceutical Bullutin, 49(9), 1226-1228.

Ishibashi, F., Satasook, C., Isman, M.B., \& Towers, G.H.N. (1993). Insecticidal $1 H$ Cyclopentatetrahydro $[b]$ benzofurans from Aglaia odorata. Phytochemistry, 32, 307-310.

Joycharat, N., Plodpai, P., Panthong, K., Yingyongnarongkul, $\quad$ B., $\quad$ \& Voravuthikunchai, S.P. (2010). Terpenoid constituents and antifungal activity of Aglaia forbesii seed against phytopathogens. Canadian Journal of Chemistry, 88, 937-944.

Khalit, M., Martin, M.T., Leroy, E., Tempete, C., Sevenet, T., Awang, K., \& Pais, M. (1999). Argenteanones C-E and argenteanols B-E, cytotoxic cycloartanes from Aglaia argentea. Phytochemistry, 51, 1031-1037.

Lee, S.K., Cui, B., Mehta, R.R., Kinghorn, A.D., Pezzuto, J.M. (1998). Cytostatic mechanism and antitumor potential of novel 1H-Cyclopenta[b]benzofuran lignans isolated from Aglaia elliptica. Chemico-Biological Interaction, 115, 215.

Liu, S., Liu, S.B., Zuo, W., Guo, Z., Mei, W., \& Dai, H. (2014). New sesquiterpenoids from Aglaia odorata var. microphyllina and their cytotoxic activity. Fitoterapia, 92, 93-99.

Mabberley, D. J., C. M. Pannel, \& A. M. Sing,. (1995). Flora Malesiana: Series I. Vol 12. Leiden. Netherlands. pp. 1-407

Mohamad, K., Martin, M.T., Najdar, H., Gaspard, G., Sevenet, T., Awang, K., Hadi, H., Pais, M. (1999). Cytotoxic 3,4-secoapotirucallanes from Aglaia argentea Bark. Journal of Natural Products, 62, 868-872.

Muellner, A.N., Samuel, R., Chase, M.W., Pannell, C.M., \& Greger, H. (2005). Aglaia (Meliaceae): an evaluation of taxonomic concepts based on DNA data and secondary metabolites. American Journal of Botony, 92(3), 534-543.

Nugroho, B.W., Edrada, R.A., Wray, V., Witte L., Bringmann, G., Gehling, M., \& Proksch, P. (1999). An insectisidal rocaglamida derivates and related compounds from Aglaia odorata (Meliaceae). Phytochemistry, 51, 367376.

Omobuwajo, O.R., Martin, M.T., Perromat, G., Sevenet, T., Awang, K., \& Pais, M. (1995). Cytotoxic cycloartanes from Aglaia argentea. Phytochemistry, 41(5), 1325-1328.

Othman, N., Pan, L., Mejin, M., Voong, J.C.L., Cai, H., Pannel, C.M., Kinghorn, D.A., Yeo, T.C. (2016). Cyclopenta[$[b]$ benzofuran and secodammarane derivatives from the stems of Aglaia stellatopilosa. Journal of Natural Products, 79(4), 784-791.

Pannell, C. M. (1992). Taxonnomic Monograph of the Genus Aglaia Lour. (Meliaceae). Kew Bulletin Additional Series XVI; HMSO: Kew, Richmond, Surrey, UK.

Roux, D., T. Martin., T., Adeline., T. Sevenet., H. Hadi., \& Pais, M. (1998). Foveolins A dan B, dammarane triterpenes from Aglaia foveolata. Phytochemistry, 49(6), 1745-1748. 
Sianturi, J., Harneti, D., Darwati, Mayanti, T., Supratman, U., \& Awang, K. (2016). A New(-)-5',6-dimethoxyisolariciresinol(3", $4^{\prime \prime}$-dimethoxy)-3 $\alpha-O-\beta$ glucopyranoside from the bark of Aglaia eximia (Meliaceae). Natural Products Research, 30, 2204-2208.

Sianturi, J., Purnamasari, M., Darwati, Harneti, D., Mayanti, T., Supratman, U., Awang, K., Hayashi, H. (2015). New bisamide compounds from the bark of Aglaia eximia (Meliaceae). Phytochemistry Letters, 13, 297-301.

Su, B., Chai, H., Mi, Q., Riswan, S., Kardono, L.B.S., Afriastini, J. J., Santarsiero, B. D., Mesecar, A. D., Fransworth, N. R., Cordell, G. A., Swanson, S. M., \& Kinghorn, D. (2006). Activity-guided isolation of cytotoxic constituents from the bark of Aglaia crassinervia collected in Indonesia. Bioorganic and Medicinal Chemistry, 14, 960-972.

Wang, B., Ebel, R., Wang, C., Edrada, R.U., Wray, V., \& Proksch, P. (2004). Aglacins I-K, three highly methoxylated lignans from Aglaia cordata. Journal of Natural Products, 67, 682-684.
Wood, D.L., Silverstain, R.M., \& Nakajima, M. (1970). Control of Insects Behavior by Natural Product. Academic Press. New York.

Wu, T.S., Liou, M.J., Kuoh, C.S., Teng, C.M., Nagao, T., \& Lee, K.H. (1997). Cytotoxic and antiplatelet aggregation principles from Aglaia ellipfolia. Journalof Natural Products, 60, 606608.

Xie, B.J., Yang, S.P, Chen, H.D., \& Yue. J.M. (2007). Triterpenoids from Aglaia duperreana. Journal of Natural Products, 70, 1532-1535.

Yodsaoue, O., Sonprasit, J., Karalai, C., Ponglimanont, C., Tewtrakul, S., \& Chantrapromma, S. (2012). Diterpenoids and triterpenoids with potential antiinflammatory activity from the leaves of Aglaia odorata. Phytochemistry, 76, 8391.

Zhang, F., Wang, J.S., Gu, Y.C., \& Kong, L.Y. (2010). Triterpenoids from Aglaia abbreviata and their cytotoxic activities. Journal of Natural Products, 73, 20422046. 